SJ Quinney College of Law, University of Utah Utah Law Digital Commons

Utah Law Faculty Scholarship

Utah Law Scholarship

$2-2019$

\title{
Private Law, Conflict of Laws, and a Lex Mercatoria of Standards-Development Organizations
}

Jorge L. Contreras

S.J. Quinney College of Law, University of Utah, jorge.contreras@law.utah.edu

Follow this and additional works at: https://dc.law.utah.edu/scholarship

Part of the Intellectual Property Law Commons

\section{Recommended Citation}

Contreras, Jorge L., "Private Law, Conflict of Laws, and a Lex Mercatoria of Standards-Development Organizations" (2019). Utah Law Faculty Scholarship. 155.

https://dc.law.utah.edu/scholarship/155

This Article is brought to you for free and open access by the Utah Law Scholarship at Utah Law Digital Commons. It has been accepted for inclusion in Utah Law Faculty Scholarship by an authorized administrator of Utah Law Digital Commons. For more information, please contact valeri.craigle@law.utah.edu. 


\title{
TILBURG PRIVATE LAW WORKING PAPER SERIES
}

No. 04/2019

\section{"Private Law, Conflict of Laws, and a Lex Mercatoria of Standards-Development Organizations"}

\author{
Jorge L. Contreras \\ Professor of Law, University of Utah S.J. Quinney \\ College of Law \\ jorge.contreras@law.utah.edu

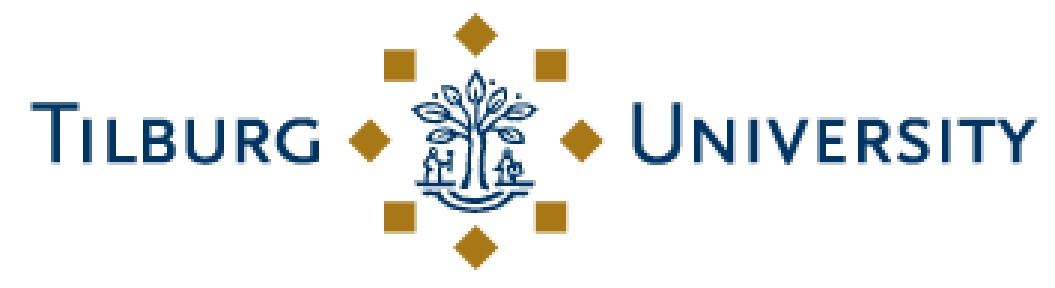 \\ Understanding Society
}

FACULTY OF LAW 


\section{Private Law, Conflict of Laws, and a Lex Mercatoria of Standards- Development Organizations}

Jorge L. Contreras*

\section{Introduction: Standards, SDOs and Conflict of Laws}

The development of technical standards such as Wi-Fi, Bluetooth and USB has been conducted largely within private industry associations known as standards-development organizations or SDOs. While an SDO provides an open forum for standards development, the technical work of standardization is generally carried out by representatives of firms having expertise in the relevant technical field: namely, technology developers and manufactures of standardized products, with the occasional involvement of governmental entities and civil society members.

The standards that emerge from SDOs enable products manufactured by different producers around the world to interoperate without significant user intervention. Large swaths of the global technology infrastructure not only depend on, but are literally defined by, these standards. As such, SDOs have been characterized as private regulators with significant public functions. ${ }^{1}$ And while a range of national and international legal regimes -- including trade law, antitrust and competition law and national standardization regulations -- impose constraints on SDO behavior, generally requiring that they observe minimal "due process" requirements, the structure and governance of SDOs remains primarily a function of private ordering among their members. ${ }^{2}$

SD0s assume a range of forms, from non-profit corporations to trade associations to contractual consortia to international non-governmental organizations. ${ }^{3}$ In each of these cases, the rules that govern the standardization process, as well as the rights and responsibilities of SDO participants, are codified in written instruments known variously as bylaws, memoranda of understanding, membership agreements, operating procedures, and the like. These policy instruments specify the procedures to be used in proposing, developing, and approving technical standards, as well as means for resolving disputes among SDO participants and the manner in which the SDO itself is governed (e.g., through elected or appointed bodies having specified authority).

\footnotetext{
* Jorge L. Contreras is Professor of Law at the University of Utah S.J. Quinney College of Law. The author is grateful to Anna Beckers, Tim Lytton, Rob van Gestel, Paul Verbruggen, Dan Wielsch and the other participants at the Regulating Private Regulators conference held at Tilburg University in May 2018, and the 2018 Intellectual Property Scholars Conference (IPSC) at University of California, Berkeley, for their helpful comments and feedback on this paper.

1 See J. L. Contreras, "From Private Ordering to Public Law: The Legal Framework Governing StandardsEssential Patents", 30. Harvard Journal of Law \& Technology 2017, p. (211); T. BüthE \& W. MATTLI, The New Global Rulers. The Privatization of Regulation in the World Economy (Princeton: Princeton University Press 2011).

${ }^{2}$ For an in-depth review of the exogenous legal constraints affecting SDOs, see J.A. BARON et al., "Making the Rules: The Governance of Standard Development Organizations and their Policies on Intellectual Property Rights", JRC Science for Policy Report at § 4.1 (2019).

3 See, generally, B. BiDDLE, "No Standard for Standards: Understanding the ICT Standards-Development Ecosystem" in J. Contreras (ed.), The Cambridge Handbook of Technical Standardization Law, Volume I: Competition, Antitrust and Patents (New York: Cambridge University Press 2017), pp. 17-28 (discussing ecosystem of standards development).
}

Tilburg Institute for Private Law. This paper can be downloaded without charge at the Social Science Research Network http:// www.ssrn.com/link/Tilburg-Private-Law.html 
Despite the international composition of SDO membership, each SDO is also organized as a legal entity in a particular jurisdiction (e.g., a U.S. state, a European country, or another jurisdiction). As such, different SDO's policies are subject to a range of national laws. ${ }^{4}$ Likewise, when disputes regarding SDO policy are litigated in national courts, different national laws are applied to the adjudication of those disputes. ${ }^{5}$ While the application of national law to private undertakings may, at first glance, seem unremarkable, it has presented unanticipated and difficult issues in the context of SDOs. Several factors have contributed to these difficulties. First, many SDOs have policies covering identical concepts, such as the requirement to license certain patents on terms that are "fair, reasonable and nondiscriminatory" (FRAND). Yet the national laws governing these SDO policies, as well as judicial approaches to contract interpretation and construction, may differ significantly. ${ }^{6}$ Second, many disputes concerning SDO policies are adjudicated in jurisdictions other than those whose laws govern the SDO's policies, requiring different courts to make decisions on matters of foreign law. What's more, none of those courts coordinate their decisions or legal interpretations, giving rise to a cacophony of different interpretations of virtually the same SDO policy provisions.

This interpretive disharmony has created uncertainty in the marketplace and unpredictability in the resolution of disputes. ${ }^{7}$ The central question raised by this article is whether a uniform body of interpretations of SDO policy provisions can be developed based on industry practice and understanding, rather than the application of national law. In essence, a lex mercatoria, or common lexicon, of technical standardization. As such, the privately derived understandings of participants in the standard-setting process can supersede, and be adopted into, national law, just as private models of governance came to supersede applicable legal regulations in the area of mercantile law and other contexts. ${ }^{8}$

\footnotetext{
4 See T. BARTLEY, "Transnational Governance as the Layering of Rules: Intersections of Public and Private Standards", 12. Theoretical Inquiries in Law 2011, p. (517), at 521 ("implementation of [...] standards always occurs within a particular nation-state, where domestic law still holds sway").

${ }^{5}$ For a summary of FRAND-related litigation around the world, see C. PENTHEROUDAKIS \& J. A. BARON, Licensing Terms of Standard Essential Patents: A Comprehensive Analysis of Cases. JRC Science for Policy Report EUR 28302 (2017). This paper focuses largely on cases and disputes in the U.S. and Europe (principally UK and Germany), as these are the jurisdictions that have seen the greatest level of FRAND litigation.

${ }^{6}$ See, e.g., P. Verbruggen, "Private Regulatory Standards in Commercial Contracts: Questions of Compliance", in: R. Brownsword, R. van Gestel \& H. Micklitz (eds), Contract and Regulation: A Handbook on New Methods of Law Making in Private Law (Cheltenham: Edward Elgar 2017), pp. 284-322, at 312 ("what normative theory a court will apply [to interpret a contract] will of course depend on law applicable to the contract under the rules of private international law").

7 This disharmony has been noted as a feature of international legal regimes, more generally. See B. M. Cremades \& S. L. Plehn, "The New Lex Mercatoria and the Harmonization of the Laws of International Commercial Transactions" 2. Boston University International Law Journal 1984, p. (317), at 320 ("today's nations realize that piecemeal regulation of international commerce through the application of independent national laws impedes the growth of international trade").

8 See, e.g., BARTLEY (n 4), at 518-19 (reviewing literature on private governance as filling regulatory voids in areas such as labor and environment). See $\mathrm{n} 75$, infra, and accompanying text, discussing assimilation of lex mercatoria into national commercial law.
}

Tilburg Institute for Private Law. This paper can be downloaded without charge at the Social Science Research Network http:// www.ssrn.com/link/Tilburg-Private-Law.html 


\section{SDO Policies - Patents and FRAND}

In recent years, one of the most contentious areas of SDO rulemaking has concerned intellectual property, particularly with regard to patents that are considered "essential" for a product to comply with a standard (so-called "standards-essential patents" or "SEPs"). ${ }^{9}$ There is a large and varied theoretical literature concerning the potential effects that SEPs may have on markets for standards-compliant products. ${ }^{10}$ One of the principal areas of debate concerns whether SEP owners can and do "hold-up" the market by demanding excessive royalty rates after a standard has been widely adopted and manufacturers have made substantial capital investments in the standardized technology (thus becoming "locked-in"). ${ }^{11}$ Another potential issue is "royalty stacking," which, as the U.S. Court of Appeals for the Federal Circuit has explained, can occur "when a standard implicates numerous patents, perhaps hundreds, if not thousands," each of which can bear a royalty and which "may become excessive in the aggregate." 12

Many SDOs have adopted policies designed to mitigate the threats of patent holdup and stacking. These policies fall into two general categories which are not mutually exclusive: disclosure policies and licensing policies. ${ }^{13}$ Disclosure policies require SDO participants to disclose SEPs that they hold, generally prior to the approval of a relevant standard. Licensing policies require SEP holders to grant manufacturers of standardized products licenses on terms that are either royalty-free or bear royalties that are "fair, reasonable and nondiscriminatory" (FRAND). ${ }^{14}$

Initially, these policies were relatively brief and abstract, requiring, for example, only that "[s]tandards should not include items whose production is covered by patents unless the patent holder agrees to and does make available to any interested and qualified party a license on reasonable terms ..."15 These loosely specified policies remained in effect through the 1990s when they began to attract greater scrutiny from litigants and courts. The situation came to a head in 2003, when semiconductor designer Rambus, Inc. avoided liability for failing to

\footnotetext{
${ }^{9}$ A patent is generally considered to be "essential" to a standard if the claims of the patent must be infringed by any product that complies with the standard. See, generally, J. L. CONTRERAS, "Essentiality and StandardsEssential Patents" in Contreras (n 3), pp. 209-230 (discussing essentiality).

${ }^{10}$ See, e.g., J. L. ContrerAS, "Technical Standards, Standard-Setting Organizations and Intellectual Property: A Survey of the Literature (with an Emphasis on Empirical Approaches)" in P. S. MENELL \& D. SchwARTZ (eds.), Research Handbook on the Economics of Intellectual Property Law, Vol. II - Analytical Methods (forthcoming 2019), § II.E-G.

11 See, e.g., J. FARRELl, ET AL., "Standard Setting, Patents, and Hold-Up", 74. Antitrust Law Journal 2007, p. (603), at 616; M. Lemley \& C. Shapiro, "Patent Holdup and Royalty Stacking", 85 Texas Law Journal 2007, p. (1991); U.S. Dep’t of Justice \& Fed. Trade Comm'N, Antitrust Enforcement and Intellectual Property Rights: Promoting Innovation and Competition 2007, p 34-35.

12 Ericsson, Inc. v. D-Link Sys., Inc., 773 F.3d 1201, 1229 (Fed. Cir. 2014).

${ }^{13}$ See American Bar Association, Standards Development Patent Policy Manual 31-85 (Jorge L. Contreras ed., 2007) (detailed catalog of SDO policy terms); M. A. LEMLEY, "Intellectual Property Rights and StandardSetting Organizations”, 90. California Law Review 2002, p. (1889) (survey of SDO policy provisions).

${ }^{14}$ See ABA Patent Policy Manual (n 13), at 56-67.

${ }^{15}$ Am. Standards Assn., Procedures of American Standards Association, Sec. 11 (1959).
} 
disclose patents essential to an SDO's standards because, the court held, the SDO's patent policy suffered from "a staggering lack of defining details." 16

Critiques such as this, together with increasing litigation among SDO participants, led several prominent SDO to revamp their patent policies in the early- and mid-2000s. ${ }^{17}$ Some of the amendments adopted by SDOs were controversial. For example, in 2006 the VMEBus Standards Association ("VITA") amended its patent policy to require advance (ex ante) disclosure of patent licensing terms and royalty rates, a requirement that generated significant opposition from patent holders. ${ }^{18}$ Two other SDOs, the European Telecommunications Standardisation Institute (ETSI) and the Institute of Electrical and Electronics Engineers Standards Association (IEEE-SA), also considered such a requirement during this time period but faced significant internal opposition and eventually adopted a voluntary, rather than a mandatory, ex ante disclosure policy. ${ }^{19}$ More recently, SDOs have continued to experiment with policy changes, most notably in 2015, when IEEE-SA sought to clarify certain aspects of its FRAND licensing commitment and limited the right of SEP holders to seek injunctive relief against manufacturers of standardized products. ${ }^{20}$ As a result, IPR policies at the most active SDOs in the information and communications technology (ICT) sector have become both complex and controversial, while at the same time remaining intentionally vague about key policy terms such as "reasonable" and "nondiscriminatory".

\section{SDO Policy Disputes}

Given the inherent vagueness of most SDO FRAND commitments, parties concerned about IPR sometimes disagree over the meaning of such commitments. Many of these disagreements relate to the level of royalties that may be demanded by a SEP holder in compliance with its FRAND commitment. There are countless details regarding the calculation of royalty rates that can cause such disagreements, including the appropriate "base" against which the royalty is calculated, ${ }^{21}$ whether different rates should apply to sales in different countries, whether adjustments should be made based on the volume sold by the manufacturer, and whether the value of the SEP holder's patents should be assessed in light of the overall number of patents covering a standard or on an individual basis. Disagreements also arise over the "non-discrimination" prong

\footnotetext{
16 Rambus, Inc. v. Infineon Techs. AG, 318 F.3d 1081, 1102 (Fed. Cir. 2003).

17 For quantitative analyses of these policy changes, see J.TSAI \& J. D. WRIGHT, "Standard Setting, Intellectual Property Rights, and the Role of Antitrust in Regulating Incomplete Contracts", 80 Antitrust Law Journal 2015, p. (157), at 159-160 and A. LAYNE-FARRAR, "Proactive or Reactive? An Empirical Assessment of IPR Policy Revisions in the Wake of Antitrust Actions", 59. Antitrust Bulletin 2014, p. (373).

${ }^{18}$ See J. L. ContrerAS, "Technical Standards and Ex Ante Disclosure: Results and Analysis of an Empirical Study", 53. Jurimetrics 2013, p. (163), at 172-75 (describing the VITA policy amendments).

19 Ibid.

${ }^{20}$ See M. A. Lindsay \& K. Karachalios, "Updating a Patent Policy: The IEEE Experience", CPI Antitrust Chronicle, Mar. 2015.

${ }^{21}$ E.g., is a percentage royalty charged against the price of the end product (e.g., a smartphone) or against the chip or component that actually embodies the standardized technology (e.g., the Wi-Fi or radio chip used in a smartphone). In technical terms, the question often posed is whether a SEP holder's royalty is charged against the value of the smallest saleable patent practicing unit (SSPPU) or the entire market value of the end product (EMV). See, e.g., Ericsson, Inc. v. D-Link Sys., Inc. (n 12), at 1020.
}

Tilburg Institute for Private Law. This paper can be downloaded without charge at the Social Science Research Network http://www.ssrn.com/link/Tilburg-Private-Law.html 
of the FRAND commitment, with parties clashing over whether a SEP holder's charges may vary based on the uses to which the end customer puts a standardized product, whether a SEP holder may choose to license only at a particular level in the supply chain (e.g., end product manufacturers rather than component manufacturers), whether royalty rates may vary based on the size or market or country of the manufacturer, and whether a SEP holder has any latitude to charge different rates to differently-situated licensees. ${ }^{22}$

Finally, in addition to the financial terms of SEP licenses, disagreements may arise over the appropriateness and scope of various non-financial terms such as requirements of reciprocal licensing, mandatory grant-back licenses, and defensive suspension. ${ }^{23}$ The greatest irony of this fractious system is that its goal is standardization. And while interoperability and standardization have been achieved to a significant degree on the technological front, the policy and legal landscape in this area has become increasingly fragmented.

\section{Public versus Private Law Enforcement}

Given this fertile ground for disagreement, an increasing number of formal disputes have arisen regarding the meaning of FRAND commitments and a growing number of courts and arbitration tribunals around the world have been called upon to interpret them. ${ }^{24}$ In these disputes, a clear intellectual divide has emerged over the most suitable legal mechanisms for enforcing such commitments. On one hand, if standard setting is a public activity, it may warrant traditional "public law" regulation. On the other hand, if standard setting is viewed as an inherently private activity, standardization may be more aptly regulated through self-policing and private law mechanisms.

A number of governmental enforcement agencies around the world have supported the application of competition and antitrust law to police private breaches of commitments made within SDOs. ${ }^{25}$ As the U.S. FTC recently noted, "[w]hile not every breach of a FRAND licensing obligation will give rise to [antitrust] concerns, when such a breach tends to undermine the standardsetting process and risks harming American consumers, the public interest demands action rather than inaction." 26 An approach to FRAND commitments grounded in competition law is also prevalent in Europe, where the dominant analysis arises under the competition analysis set out by the CJEU in Huawei $v$. $Z T E,^{27}$ and where the UK High Court (Patent) in Unwired Planet v. Huawei28

\footnotetext{
22 See, generally, J. L. Contreras \& A. LAYNe-FarraR, "Non-Discrimination and FRAND Commitments" in CONTRERAS (n 3), pp. 186-208.

${ }^{23}$ See, generally, ABA Patent Policy Manual (n 13).

${ }^{24}$ See Pentheroudakis \& Baron (n 5) (cataloging FRAND litigation around the world).

${ }^{25}$ For an overview of these actions, see J. L. ConTRERAS, "The Global Standards Wars: Patent and Competition Disputes in North America, Europe and Asia" (Apr. 2018), https://papers.ssrn.com/sol3/papers.cfm?abstract_id=3106090.

26. Fed. Trade Comm'n, Statement of the Federal Trade Commission on In the Matter of Robert Bosch GmbH, FTC File Number 121-0081 (Nov. 26, 2012).

27 CJEU 16 July 2015, C-170/13, Huawei Technologies Co. Ltd v. ZTE Corp. and ZTE Deutschland GmbH, ECLI:EU:C:2015:477.

${ }^{28}$ [2017] EWHC 711 (Pat) (Apr. 5, 2017), aff'd [2018] EWCA Civ. 2344 (23 Oct. 2018).
} 
evaluated numerous aspects of the SEP holder's FRAND commitment through a lens of competition rather than contract law. ${ }^{29}$

On the other side of this debate, the U.S. Department of Justice Antitrust Division has recently adopted the position that antitrust enforcement and remedies should be used only sparingly in the context of standard setting, and that traditional private law remedies such as contract are preferable for policing compliance with FRAND commitments. ${ }^{30}$ Some commentators have also argued that private legal remedies (contract and tort) should suffice to redress most issues arising in standard setting, and that a resort to public law remedies (antitrust) is both unnecessary and counterproductive. ${ }^{31} \mathrm{I}$, too, believe that while antitrust and competition law remedies must remain available to address instances of deception and other forms of abusive conduct, the essential contours of SDO policies and FRAND commitments, which at their root are privately ordered arrangements among parties, can only be discerned through the application of private law mechanisms. ${ }^{32}$ As I have written previously, "Despite the public nature of standards development, the most efficient and equitable way to resolve disputes regarding the conduct of participants in the standardization process may be to focus on the scope and nature of the parties' privately ordered arrangements." 33 That is, the adjudicatory focus should be on what the parties actually intended by the language of the commitments that they made. Accordingly, the focus of this paper is on the application of private law, particularly contract law, to SDO policy interpretation and enforcement.

\section{National Law and SDO Policies - The Accidents of Geography}

By their nature as legal entities, most SDOs are established in a particular legal jurisdiction. For example, the International Telecommunications Union (ITU) is based in Geneva, Switzerland, the European Telecommunications Standardisation Institute (ETSI) is based in Sophia-Antipolis, France, the Institute of Electrical and Electronics Engineers Standards Association (IEEE-SA) is based in New York, New York, USA, and the Internet Engineering Task Force (IETF) is based in Reston, Virginia, USA. The foundational legal documents establishing each of these SDOs are thus drafted according to the laws of the SDO's home jurisdiction and are often filed with relevant state and national business registries.

\footnotetext{
${ }^{29}$ See J. L. Contreras, "Global Markets, Competition and FRAND Royalties: The Many Implications of Unwired Planet v. Huawei", 16. Antitrust Source 2017, August 2017.

30 Asst. Atty. Gen. Antitrust Div., U.S. Dept. Justice, MaKan Delrahim, "Take it to the Limit: Respecting Innovation Incentives in the Application of Antitrust Law", Remarks as Prepared for Delivery at the USC Gould School of Law, Nov. 10, 2017, https://www.justice.gov/opa/speech/file/1010746/download.

31. See B. H. Kobayashi \& J. D. WRight, "Federalism, Substantive Preemption, and Limits on Antitrust: An Application to Patent Holdup", 5. Journal of Competition Law \& Economics 2009, p. (469), at 506-516 (discussing the comparative advantage of tort and contract law in regulating breaches of FRAND commitments); see also H. HovenkAmp, "Antitrust and the Patent System: A Reexamination", 76. Ohio State Law Journal 2015, p. (467), at 555 ("Fundamentally, these are problems best addressed through the patent system rather than by antitrust law").

32 See J. L. CONTRERAS (n 1).

33 Ibid, at 230 .
}

Tilburg Institute for Private Law. This paper can be downloaded without charge at the Social Science Research Network http:// www.ssrn.com/link/Tilburg-Private-Law.html 
Likewise, the policy documents setting forth the rules and procedures of each of these SDOs purports to be governed by the laws of a particular legal jurisdiction, usually the home jurisdiction of the SDO. Thus, ETSI declares that its IPR policy "shall be governed by the laws of France." ${ }^{4}$ Other SDOs such as IEEE-SA do not specify the particular jurisdiction whose laws govern its policy documents, but courts interpreting those documents - particularly U.S. courts -- interpret them in accordance with their general understandings of local law. Thus, on top of the intricacies of the written rules governing SDO participation, a further layer of complexity is introduced by the national and state laws that provide the analytical and enforcement framework around these rules.

The application of specific national laws and modes of legal interpretation to already complex SDO policies has introduced an additional level of unpredictability to the interpretation of SDO policies, particularly surrounding FRAND commitments. For example, in Apple v. Motorola, a federal district court sitting in Wisconsin was required to determine whether the SEP holder, Motorola, violated its contractual obligation to offer a FRAND license to Apple. In assessing Motorola's obligation under IEEE's patent policy, the court observed that "Neither party undertakes an adequate choice of law analysis with respect to claims concerning IEEE, and both sides cite variously to Wisconsin, New York and Illinois law in support of their respective positions." 35 To resolve the matter, the court determined that there was no conflict among the laws of New York, Illinois and Wisconsin with respect to the relevant issues in the case, and thus proceeded to apply the laws of Wisconsin, though neither party had any material relationship with the state of Wisconsin. ${ }^{36}$

Even more striking have been the efforts of courts to apply French law to the interpretation of ETSI's patent policy. In Apple v. Motorola, the same Wisconsin court, turning to Motorola's FRAND obligations under ETSI's patent policy, based its interpretation of French law governing the ETSI policy on a French law professor's affidavit submitted on behalf of one party, and the other party's excerpt from an English language treatise on French contract law. ${ }^{37}$ With these resources in hand, the court appears to rely on the expert's assertion that French law "requires the same general elements" for contract formation as Wisconsin law, and makes little effort to apply French statutory law to the case. ${ }^{38}$ In Unwired Planet v. Huawei ${ }^{39}$, the UK High Court (Patent) makes a significantly greater effort to understand and interpret the French law applicable to ETSI's patent policy, thoughtfully probing the arguments of both parties' experts over

\footnotetext{
34 ETSI, Rules of Procedure, 29 Nov. 2017, Annex 6, Sec. 12.

35886 F. Supp. 2d 1061, 1082 (W.D. Wis. 2012). Interestingly, the state of Wisconsin bore no relationship whatsoever to the parties or the case. The case was originally brought in Illinois, given Motorola's Chicago headquarters. Yet for case management reasons, the case was bifurcated, with one set of issues (those concerning patent infringement) scheduled to be heard by the court in Chicago, and another set of issues (those concerning contractual matters) assigned to be heard in the neighboring federal district in Wisconsin.

36 Ibid.

37886 F. Supp. 2d at 1082.

38 Ibid., at 1083.

39 [2017] EWHC 711 (Pat) (Apr. 5, 2017).
}

Tilburg Institute for Private Law. This paper can be downloaded without charge at the Social Science Research Network http:// www.ssrn.com/link/Tilburg-Private-Law.html 
many pages of the opinion. ${ }^{40}$ A similar effort was made by the U.S. district court in TCL v. Ericsson based on competing affidavits of the parties' French law experts. ${ }^{41}$ Yet one must wonder how consistent and accurate these renditions of French law in Wisconsin, California and the U.K. can be, especially when based on nothing more than the advocacy of paid experts.

U.S. law introduces further complexities to the interpretation and analysis of SDO FRAND commitments that do not translate well to other countries. For example, in the U.S. the primary statutory measure of damages for patent infringement is a "reasonable royalty".42 For the past several decades, the calculation of reasonable royalty damages in the U.S. has generally followed the 15-factor "hypothetical negotiation" framework established in Georgia-Pacific Corp. v. U.S. Plywood Corp. ${ }^{43}$ Because FRAND commitments speak in terms of a "reasonable" royalty, several U.S. courts have sought to determine the appropriate level of royalties under a FRAND commitment utilizing traditional methodologies for determining patent damages, including the Georgia-Pacific hypothetical negotiation framework. However, because this framework assumes that the patent holder and the infringer have no pre-existing relationship, many of the assumptions underlying this analysis do not apply in cases involving FRANDencumbered SEPs. This inconsistency has been pointed out in several cases. In Microsoft v. Motorola, for example (in which the Georgia-Pacific analysis was applied to a FRAND commitment made to ITU, notwithstanding the fact that ITU is a Geneva-based SDO with no acknowledgement of U.S. law), the court expressly modified twelve of the Georgia-Pacific factors when conducing its FRAND analysis. ${ }^{44}$ Likewise, in Ericsson v. D-Link, the Court of Appeals for the Federal Circuit criticized the use of several Georgia-Pacific factors when calculating royalties subject to a [F]RAND commitment. These criticisms suggest that the Georgia-Pacific framework is not well-suited to the determination of royalty levels complying with FRAND requirements even with respect to FRAND commitments made to U.S. SDOs, let alone non-U.S. SDOs such as ITU and ETSI. And, not surprisingly, courts outside the U.S. have not used the Georgia-Pacific analysis when interpreting SDO FRAND commitments.

Other examples of potential jurisdictional divergence exist. For example, jurisdictions may differ in how they treat a FRAND commitment when the original SDO participant that made it transfers the underlying SEP to a third party. Do such commitments travel with patents, binding their new owners, or are they binding only on the original promisor? Likewise, a SEP holder commits to an SDO that it will grant licenses to potential implementers of a standard on FRAND terms. But the implementer and SEP holder lack "privity of contract", so if the SEP holder breaches its commitment, the implementer must bring suit against the SEP holder as a "third party beneficiary" of the SDO-SEP holder commitment. Under U.S. law, courts have long recognized third party beneficiary claims, and at least two federal district courts have adopted this theory with

\footnotetext{
40 [2017] EWHC 711 at paras 103-146.

41 TCL v Ericsson (C.D. Cal. 2018).

4235 U.S.C. $\S 284$.

43 Georgia-Pacific Corp. v. U.S. Plywood Corp. (S.D.N.Y. 1970).
} 
respect to FRAND commitments. ${ }^{44}$ However, application of the third-party beneficiary doctrine to FRAND commitments presents doctrinal challenges, both in the U.S. and elsewhere. ${ }^{45}$ In fact, several countries have never recognized the doctrine, and in the U.K. it has been adopted by statute but was not recognized under the common law. 46

Given these and other issues, including the fact that some key questions in the U.S. are determined by a lay jury, some non-U.S. courts have begun to distance themselves from the reasoning of U.S. cases. The most pronounced example of this distancing occurs in Unwired Planet, in which the U.K. court expressly rejects several touchstones of SDO policy analysis developed in the U.S. For example, both courts ${ }^{47}$ and enforcement agencies ${ }^{48}$ in the U.S. have concluded that a FRAND royalty should reflect the ex ante value of a patented technology, without considering the added value attributable to the adoption of the technology in a standard. ${ }^{49}$ Yet the court in Unwired Planet, while acknowledging these prior analyses, expressly parts ways with its U.S. counterparts with little explanation. ${ }^{50}$ Similarly, the UK court in Unwired Planet pronounces that there is but a single FRAND rate for any given licensing transaction, explicitly deviating from the approach taken by the U.S. court in Microsoft $v$. Motorola, in which a range of FRAND rates was determined. 51

The national law overlay on SDO-related commitments thus introduces numerous inconsistencies to the analysis of SDO policies and FRAND commitments. First, it is often unclear which body of law to apply to a given SDO policy. Second, even if there is no disagreement over the correct body of law, the interpretation of that law may be based on scant knowledge and experience (e.g., applying French law in Wisconsin). Third, the particular analytical tools of one jurisdiction (e.g., the U.S. Georgia-Pacific framework) will not necessarily be

44Microsoft Corp. v. Motorola, Inc., 854 F. Supp. 2d 993, 1002-03 (W.D. Wash. 2012); Apple, Inc. v. Motorola Mobility, Inc., 886 F. Supp. 2d 1061, 1085 (W.D. Wis. 2012).

${ }^{45}$ For a detailed discussion of the third party beneficiary theory as applied to FRAND commitments, see J. L. Contreras, "A Market Reliance Theory for FRAND Commitments and Other Patent Pledges", Utah Law Review 2015, p.(479) at 508-514. ; J. G. SIDAK, “A FRAND Contract's Intended Third Party Beneficiary, 1. Criterion J. Innovation 2016, p. (1001). Cf. VERBRUGGen (n 6), at p. 317-320 (discussing difficulty of enforcing codes of conduct embodied in supply chain agreements under third party beneficiary theory in the U.S.).

46 See V. V. Palmer, The Paths to Privity: A History of Third Party Beneficiary Contracts at English Law San Francisco: Austin \& Winfield 1992), p. 165-167 (1992) and U.K. Contracts (Rights of Third Parties) Act 1999. See also M.A. EISEnBERG, "Third-Party Beneficiaries", 92. Columbia Law Review 1992, p. 1358, 13641365; J. HallebeEK, "Contracts for a Third Party Beneficiary: A Brief Sketch from the Corpus Iuris to Present Day Civil Law” (Working Paper 2007), https://research.vu.nl/ws/portalfiles/portal/2330470.

47 Ericsson v. D-Link, 773 F.3d at 1232; In re Innovatio IP Ventures, LLC Patent Litig., 921 F. Supp. 2d 903, 907 (N.D. Ill. 2013); Microsoft Corp. v. Motorola, Inc., Findings of Fact and Conclusions of Law, 2013 U.S. Dist. LEXIS 60233 at *44 (W.D. Wash., Apr. 25, 2013), aff'd 795 F.3d 1024 (9th Cir. 2015).

48 Fed. Trade Comm'n, The Evolving IP Marketplace: Aligning Patent Notice and Remedies with Competition, $\mathrm{p}$. 22-23 (2011) ("A definition of [F]RAND based on the ex ante value of the patented technology at the time the standard is chosen is necessary for consumers to benefit from competition among technologies to be incorporated into the standard").

${ }^{49}$ See, e.g., FARRELL, ET AL. (n 11), at 603.

50 [2017] EWHC 711, at para 97. For a more detailed discussion of this aspect of the Unwired Planet decision, see CONTRERAS (n 29), at 8.

51 Compare Unwired Planet, [2017] EWHC 711 at para 804(4) with Microsoft v. Motorola, 2013 U.S. Dist. LEXIS 60233 at *303. The High Court's ruling on this point was found to be in error on appeal, though not because it deviated from the U.S. decisions. [2018] EWCA Civ 2344 at para 121.

Tilburg Institute for Private Law. This paper can be downloaded without charge at the Social Science Research Network http:// www.ssrn.com/link/Tilburg-Private-Law.html 
used in other jurisdictions, even when the same SDO policy is being interpreted. And, finally, courts in one jurisdiction may simply differ in their analysis from those in other jurisdictions, thus leading to incompatible interpretations of the same SDO policy.

\section{National Law and Global Markets}

The UK High Court (Patents) in Unwired Planet ${ }^{52}$ introduced yet another wrinkle to the fabric of FRAND adjudication. In that case, Unwired Planet, the holder of several SEPs covering 2G, 3G and 4G wireless telecom standards, had allegedly offered to grant Huawei, a Chinese smartphone manufacturer, a worldwide license under those SEPs. Huawei challenged the reasonableness of Unwired Planet's licensing offer and the parties commenced litigation in several countries, including the UK. In the UK case, Huawei argued that it only wished to obtain a license under Unwired Planet's UK patents, 53 and that Unwired Planet's insistence on a worldwide license was unreasonable.

In evaluating the reasonableness of Unwired Planet's proffered license, the UK court first observed that "the vast majority" of SEP licenses in the wireless telecom industry, including all of the comparable licenses introduced at trial, were granted on a worldwide basis, with only occasional exclusions. ${ }^{54}$ Against this backdrop, the court reasoned that "a licensor and licensee acting reasonably and on a willing basis would agree on a worldwide licence". ${ }^{55}$ In contrast, the court found that country-by-country licensing, as proposed by Huawei, would be extremely inefficient if not "madness". ${ }^{56}$ Accordingly, the court ruled that, in this case, a FRAND license was necessarily a worldwide license and that if Huawei did not enter into a license agreement on the global FRAND terms dictated by the court, it would suffer the entry of an injunction in the UK (a sizable market). ${ }^{57}$ Once Huawei enters into that license agreement, it will be licensed across the entire world at the rates set by the UK court. No further licenses will be needed, and proceedings in all other jurisdictions will effectively be mooted.

The UK court's decision in Unwired Planet raises the very real possibility that national courts will feel increasingly entitled to set royalty rates for SEPs across the globe. The implications of this trend could be material, as high stakes patent litigation today is an inherently global enterprise with parallel actions brought in a dozen or more jurisdictions. ${ }^{58}$ This localized power to affect global commercial

\footnotetext{
52 [2017] EWHC 711 (Pat) (Apr. 5, 2017).

53 Id. at para 524.

54 Ibid, at para 534. Some comparable licenses, for example, excluded China.

$55 \mathrm{Ibid}$, at para 543.

56 Ibid, at para 543.

57 Ibid, at para 572, 807(18). A similar result was reached by the Landgericht Düsseldorf in Saint Lawrence Communications v. Vodafone, Landgericht Düsseldorf 4a 0 73/14, 4a 0126/14, 4a 0 127/14, 4a 0 128/14, 4a 0 129/14, 4a 0 130/14, 31 March 2016. In Vodafone, the SEP holder also offered the implementer a worldwide license, which requested instead a n national license. In evaluating the SEP holder's conduct under Huawei v. ZTE, the lower court held that the offer for a worldwide license was FRAND compliant. See Robin Jacob \& Alexander Milner, Lessons from Huawei v. ZTE, 4iP Council Research Report, Oct. 2016, at 10, http://www.4ipcouncil.com/news/latest-research-4ip-council-lessons-huawei-v-zte.

58 See, e.g., J. ELLIS, "Vringo and ZTE Go the Distance: An Infographic", Intell. Asset Mgmt. Blog (Dec. 15, 2015), https://perma.cc/2MUJ-YY63 (describing litigation between Vringo and ZTE in twelve different
}

Tilburg Institute for Private Law. This paper can be downloaded without charge at the Social Science Research Network http:// www.ssrn.com/link/Tilburg-Private-Law.html 
relationships could embolden courts in particular jurisdictions to seek to attract litigants based on their interpretations of certain key SDO policy provisions. Thus, the interpretations of some jurisdictions might favor SEP holders, attracting them to the courts of that jurisdiction much as U.S. patent holders were once attracted to the patent-friendly District Court for the Eastern District of Texas, ${ }^{59}$ and European patent holders are attracted to Germany, where injunctive relief will often be granted in an expedited proceeding before patent validity is adjudicated. 60 By the same token, jurisdictions that gain reputations for favoring implementers over SEP holders may find a dearth of SEP holders seeking adjudication in their courts, but perhaps an increase in claims by manufacturers of standardized products.

This state of affairs can lead to what is termed a "race to the courthouse", as litigants rush to file suit in the jurisdiction most favorable to their position. The stakes in such races become even greater when any one court having jurisdiction over the parties may issue an order (a so-called "anti-suit injunction") prohibiting the parties from maintaining an action in any other jurisdiction until the issuing court has reached a decision. ${ }^{61}$ In effect, any country whose market is large enough that the manufacturer is not willing to sacrifice it via an injunction could leverage the threat of an injunction to force parties to enter into a global agreement on the terms that its courts dictate.

These considerations may also shape the behavior of courts and institutions within jurisdictions to mold their rules and procedure to attract litigation in a "race to the bottom". ${ }^{62}$ Thus, the potential for inconsistent judicial interpretations of SDO policy provisions is likely to lead both to an unproductive race to the courthouse among litigants and a race to the bottom among jurisdictions.

\section{A Lack of Precedent and Predictability}

In today's global economy, product markets span the globe and worldwide product interoperability is increasingly expected in fields such as computing,

jurisdictions), K. EICHEnWALD, "The Great Smartphone War", Vanity Fair, May 3, 2014, http://www.vanityfair.com/news/business/2014/06/apple-samsung-smartphone-patent-war (describing litigation between Apple and Samsung across a dozen jurisdictions).

${ }^{59}$ See, e.g., B. J. Love \& J. Yoon, "Predictably Expensive: A Critical Look at Patent Litigation in the Eastern District of Texas", 20. Stanford Technology Law Review 2017, p. (1). The peculiar dominance of the E.D.Tex. in U.S. patent litigation may be coming to an end following the U.S. Supreme Court's recent decision in TC Heartland LLC v. Kraft Foods Group Brands LLC, 581 U.S. (2017). See R. DAvis, "What We Know about Patent Venue Post-TC Heartland", Law360, May 23, 2018.

60 The readiness of German courts to issue injunctions to patent holders was tempered somewhat in the case of SEPs subject to FRAND commitments by the Court of Justice of the EU in Huawei v. ZTE (n 27), in which a SEP holder may be found to abuse its dominant position in violation of TFEU 102 if it seeks to obtain an injunction when enforcing a FRAND-encumbered SEP without following a specified set of procedural steps outlined by the CJEU.

61 See J. L. Contreras \& M. A. Eixenberger, "The Anti-Suit Injunction - A Transnational Remedy for MultiJurisdictional SEP Litigation" in CONTRERAS (n 3), pp. 451-459 (describing anti-suit injunctions in Microsoft v. Motorola, Vringo v. ZTE and TCL v. Ericsson).

62 See, e.g., D. J. H. GReEnwood, "Democracy and Delaware: The Mysterious Race to the Bottom/Top", 23. Yale Law \& Policy Review, Issue 2, Art. 2 (2005) (discussing the view that the U.S. state Delaware adjusted its corporate law to attract business incorporations). For a more detailed discussion of the potential impact of these developments on global markets, see CONTRERAS (n 29).

Tilburg Institute for Private Law. This paper can be downloaded without charge at the Social Science Research Network http:// www.ssrn.com/link/Tilburg-Private-Law.html 
networking, content distribution and telecommunications. The SDOs that develop standards to enable this degree of interoperability, by default, must operate internationally. Their participants come from dozens of countries around the world, particularly North America, Europe, Oceana, and Asia. ${ }^{63}$ In many cases, the same individuals participate on behalf of their employers in multiple SDOs developing similar technologies. Even SDOs such as ETSI, which began as projects of regional or national governments have, by necessity, expanded to encompass an international membership.

The physical headquarters location of SDOs has thus become increasingly irrelevant to their operation and policy making. Why should the fact that one SDO is legally based in New York and another is legally based in Geneva affect the interpretation and enforcement of commitments made by the same individuals on behalf of the same firms acting in the same technology space with respect to the very same end products?

The examples discussed above illustrate that the national and state private law mechanisms that purport to govern SDO patent policies are inconsistent and sometimes at odds with one another. The result has been an interpretive patchwork that allows room for opportunistic parties to engage in forum shopping and makes planning more difficult for everyone else. Moreover, given the different approaches taken by different jurisdictions to these issues, an adjudication in one jurisdiction relating to a FRAND commitment is not likely to assist with interpretation of that same commitment in another jurisdiction. Given the global nature of markets for standardized products, this fragmentation along national and state boundaries is particularly problematic.

What's more, there is not even predictable interpretation of identical policy provisions from one SDO to the next, even within the same country. That is, each SDO purports to be an independent organization with a unique set of governing documents and policies. As such, most SDOs feel free to disregard guidance and interpretations of policy provisions that are issued by other SDOs. Some SDOs, in fact, vehemently defend their independence in declining to follow the interpretive lead of other SDOs, even where identical policy language is concerned.

Can this fragmentation be efficient? Why should the term "non-discriminatory" have different meanings depending on whether an SDO is based in New York or Sophia-Antipolis, or whether the court adjudicating that meaning is located in London or Milwaukee? This divergence is particularly senseless when the same individuals interact at these different SDOs on a regular basis. A lack of consistency in the interpretation of common SDO provisions, even noncontroversial ones, lends less predictability to the ordering of private affairs. The lack of consistent understandings of SDO policy provisions may give rise to more disputes regarding policy interpretation and result in less certainty regarding

\footnotetext{
63 See, e.g., J. L. ContreRAS, "Divergent Patterns of Engagement in Internet Standardization: Japan, Korea and China”, 38. Telecommunications Policy 2004, p. (916) (describing globalization of Internet standardization and increasing engagement of Asian firms).
} 
the outcome of disputes. All of these lead to higher transaction and litigation costs, thus disadvantaging smaller players. ${ }^{64}$

Finally, it seems unlikely that this fragmented system can accurately reflect the understanding of individual SDO participants. Is it possible that these individuals adjust their behavior depending on the interpretations given to nearly identical SDO rules country by country, organization by organization? This cannot be the way that individual SDO participants conduct themselves, yet this is the reality imposed on them and their employers by the fragmented nature of private law mechanisms that guide interpretation of SDO policies.

\section{A Lex Mercatoria for Standardization?}

Let us conduct a thought experiment. Suppose that two engineers, call them Jacques and Mary, employed by different firms, each participate in two SDOs, one based in the U.S. and the other based in France. The patent policies of these SDOs are relatively similar. Further suppose that neither Jacques nor Mary is an attorney or an expert in legal doctrine, but that each of them has many years of experience developing technical standards and some familiarity with both the principles of patent law and his or her own employer's policies relating to patents. Assuming that neither Jacques and Mary, nor their companies, are at the moment embroiled in a dispute and view each other relatively neutrally, what can we assume about their understanding of the SDOs' policies relating to certain topics?

Let us first consider the less controversial topics raised above. Would Jacques and Mary agree that a FRAND commitment made with respect to a patent should continue if the patent is sold to a new owner? While nothing is certain, it is likely that they would agree that the FRAND commitment should, indeed, travel with the patent, even if they know nothing about competition law or the law of property servitudes. What about the ability of a third party who is not an SDO member to enforce a FRAND commitment against a SEP holder? Again, it is likely that our two engineer friends would agree that the implementer should be able to insist that a SEP holder grant it a license on FRAND terms, even if they know nothing about the convoluted law surrounding privity of contract or third party contractual beneficiaries.

What about a more controversial topic? For example, the non-discrimination prong of the FRAND commitment. Would they agree that charging one implementer $\$ 0.05$ per unit and another implementer $\$ 0.01$ per unit for a license is discriminatory? Perhaps they would. Or perhaps they, being thoughtful engineers, would want to know more, such as the relative sizes or unit volumes

\footnotetext{
64 This is not to say, however, that SDOs should not be encouraged to experiment with their IPR policies. Policy experimentation is a useful method for adapting policy terms to evolving needs of the industry. See, e.g., BARTLEY (n 4), at 524 ("Private regulation may also be conceptualized as a laboratory of standards and benchmarks to later be institutionalized in government regulation and law, another possible form of complementarity" (citing C. F. SABEL \& J. Zeituin, "Learning From Difference: The New Architectures of Experimentalist Governance in the European Union", 14. European Law Journal 2008, p. (271). Rather, the critique of this article is differing external interpretations of the same policy provisions adopted by different SDOs.
} 
sold by these two implementers, or whether their products serve different markets (e.g., wireless connectivity in offices versus automobiles). Depending on the answers to these questions, they might or might not agree on a common position. ${ }^{65}$

From the answers to these questions, we can sequentially build up a common body of understanding between Jacques and Mary as to many, but not all, issues. It is likely that if more engineers, also from different firms, were asked, some of them would agree with some of the common understandings of Jacques and Mary. As a result, we could, in theory, develop a body of policy understandings that is common across a large swath of the relevant stakeholders in the standards-development community. ${ }^{66}$

This set of common understandings could be considered a sort of lex mercatoria - a system of rules administered and interpreted not by national and state courts, but by the expert practitioners of a particular trade.67 As such, the common understanding of these policy provisions would supersede legal interpretations imposed by national or state law. In fact, it would be reasonable for legal tribunals to defer to such common trade understandings, as is frequently done in the commercial context. 68

What's more, if we conceptualize the set of policy rules enabling the development of standards across the globe as an interconnected network rather than a multiplicity of isolated nodes, we can begin to adopt learning and interpretation across SDOs, rather than compartmentalizing the interpretive activity of each SDO within itself. Thus, an SDO that gives meaning to a term not previously debated can, at minimum, influence the interpretive act of other SDOs in the network and, at most, serve as a precedent directly bearing on other SDOs' interpretation.

Of course, as noted above, uniformity will not be achievable as to every SDO policy provision, and some contentious issues, such as the appropriate base for FRAND royalty calculations, may remain disputed across SDOs. As a result, different SDOs may adopt different meanings for these disputed terms through whatever internal voting and consensus procedures they wish. Nevertheless, it is likely that there is a significant body of SDO policy provisions that do not suffer

\footnotetext{
${ }^{65}$ An actual example of SDO divergence on a controversial topic can be found with respect to the definition of FRAND. As noted above, IEEE enacted policy amendments in 2015 which seek to clarify several aspects of its participants' FRAND commitments including the appropriate royalty base (SSPPU should be considered). In contrast, CEN-CENELEC in recent policy guidelines has expressly declined to offer such interpretive advice, taking the position instead that FRAND is a mere 'comity device' which cannot be specified in advance.

${ }^{66}$ For a discussion of the development of common understandings through the mechanism of "shared meaning analysis" in the context of consumer contracts, see R. B. KAR \& M. J. RADIN, "Pseudo-Contract \& Shared Meaning Analysis", 132. Harvard Law Review 2019, p.(1135).

${ }^{67}$ See, generally, H. J. Berman \& C. KAufman, "The Law of International Commercial Transactions (Lex Mercatoria)", 19. Harvard International Law Journal 1978, p. (221) (discussing origins and contemporary application of lex mercatoria).

${ }^{68}$ See L. L. JafFe, "Law Making by Private Groups", 51. Harvard Law Review 1937, p. (201), at 213 (describing how courts adopted customs and usages of merchants in adjudicating commercial transactions).
}

Tilburg Institute for Private Law. This paper can be downloaded without charge at the Social Science Research Network http:// www.ssrn.com/link/Tilburg-Private-Law.html 
from broad disagreement, and which could form the basis for a standardization lex mercatoria.

\section{Role of a lex mercatoria?}

It is worth emphasizing that the envisioned lex mercatoria for standardization is not intended to be a replacement for judicial or arbitral resolution of FRAND disputes, but as a tool that can be employed by courts and arbitral tribunals in resolving such disputes. Courts have, in the past, given weight to the intentions of SDO participants when interpreting policy language that was ambiguous. In some cases, participant understandings have even superseded the plain meaning of policy language that did not reflect widely-held norms. ${ }^{69}$ The lex mercatoria of standardization, were it to be adopted, could more easily enable adjudicators to determine, without resort to national law, whether particular duties and practices are imposed by SDO policies, clearing the way for them to evaluate individual conduct in light of those common rules in a more consistent and efficient manner.

This being said, a common set of understandings codified into a lex is not the only way that greater consistency and predictability could be achieved in an international setting. On the contrary. Greater harmonization of national judicial interpretations could also serve this purpose, as could deference among national courts to decisions made in other jurisdictions (akin to the international recognition of arbitral awards under the New York Convention on the Recognition and Enforcement of Foreign Arbitral Awards. ${ }^{70}$ But, as desirable as these international comity measures might be, such coordination does not appear to be on the horizon in today's political environment. Moreover, the bringing together of national judicial approaches has far broader implications than standardization and FRAND licensing. As such, it is suggested that the lex mercatoria proposal in this paper, which concerns only the world of technical standard setting, is far more modest than a call for broad systemic change at a global level.

\section{Codification and Implementation}

The above discussion begs the question, of course, who would develop such a lex mercatoria, and under what circumstances? Who are Jacques and Mary, and how might we persuade them to engage in the exercise of codifying their common understandings? As Cremades and Plehn observe, there are two basic approaches to the establishment of a new international legal regime: the harmonization of existing national laws, and the development of a new, autonomous body of law. ${ }^{71}$ The harmonization approach has been used with

\footnotetext{
${ }^{69}$ See, e.g., Rambus, Inc. v. Infineon Techs. AG, 318 F.3d 1081 (Fed. Cir. 2003) (literal reading of SDO policy resulted in no duty of disclosure on SDO members, but testimony of various SDO participants showed that even without a formal disclosure requirement, SDO participants shared a common understanding that they should disclose patents necessary to practice the SDO's standards, resulting in a legal duty); Qualcomm Inc. v. Broadcom Corp., 548 F.3d 1004 (Fed. Cir. 2008) (finding similar duty to disclose patents based on informal norms and expectations of SDO participants). See also CONTRERAS (n.1) at 218-220.

70 U.N. Comm. on Intl. Trade Law, Convention on the Recognition and Enforcement of Foreign Arbitral Awards (New York, 1958).

71 See CREMAdes \& Plehn (n 7), at 321.
}

Tilburg Institute for Private Law. This paper can be downloaded without charge at the Social Science Research Network http:// www.ssrn.com/link/Tilburg-Private-Law.html 
varying degrees of success in the area of intellectual property law. Broadly adopted treaties such as the TRIPS Agreement ${ }^{72}$ have shaped the IP laws of most developed countries, but the process of negotiating an international treaty is complex, lengthy and resource-intensive, and has only become more so in recent years. Accordingly, this approach is not recommended in the current instance.

Looking to the roots of the lex mercatoria itself - the customary code of merchant law - we find the development of an autonomous body of doctrine that existed independently of formal law. Its origins have been traced to the organized mercantile markets and fairs that began to emerge in eleventh century Europe. ${ }^{73}$ The body of commercial practices and norms developed by merchants in their transactions diverged in important ways from then-existing legal doctrines, but were widely observed among transacting parties. ${ }^{74}$ Eventually, the norms developed by these private actors were recognized by courts in adjudicating disputes: first among merchants and then in commercial transactions more broadly. ${ }^{75}$ Numerous other examples of such private transactional codes have been studied, including those adopted by Hassidic diamond wholesalers, ${ }^{76}$ Memphis cotton merchants, ${ }^{77}$ credit rating agencies, ${ }^{78}$ and Internet technology users, ${ }^{79}$ to name just a few.

These examples suggest that for a private code to achieve both acceptance and legitimacy in the eyes of both its adherents and the broader legal system, it should be developed and adopted organically by those to whom it is applied, as opposed to some external body. ${ }^{80}$ Accordingly, the proposed lex mercatoria of standardization should arise from the usage and custom of the standardsdevelopment community. In fact, as illustrated by the example of Jacques and Mary in the previous Section, it is likely that this common understanding already exists in practice, and merely requires codification to be preserved and utilized effectively by courts, arbitrators and other adjudicatory bodies.

This being said, industry custom cannot be the only criteria by which a private code is judged. The question of legitimacy is particularly important if a private code of conduct is to be adopted by the legal system. Without a doubt, there are private codes that may govern behavior of their adherents (e.g., the Sicilian

\footnotetext{
72 Agreement on Trade-Related Aspects of Intellectual Property Rights (1995).

73 See CREMADES \& Plehn (n 7), at 318 fn.2 (collecting historical references); BERMAN \& KAUfMAN (n 67), at 225.

74 See Cremades \& Plehn (n 7), at 319.

75 See Berman \& Kaufman (n 67), at 226; Jaffe (n 68), at 213; Cremades \& Plehn (n 7), at 319-20.

76 L. BeRnStein, "Opting out of the Legal System: Extralegal Contractual Relations in the Diamond Industry", 21. Journal of Legal Studies 1992, p. (115).

77 L. Bernstein, "Private Commercial Law in the Cotton Industry: Creating Cooperation Through Rules, Norms, and Institutions", 99. Michigan Law Review 2001, p. (1724).

78 S. L. Schwarcz, "Private Ordering of Public Markets: The Rating Agency Paradox", University of Illinois Law Review 2002, p. (1).

${ }^{79}$ See M. A. Lemley, "The Law and Economics of Internet Norms", 73. Chicago-Kent Law Review 1998, p. (1257), 1263-1264.

${ }^{80}$ It is worth noting that while the standards engineers who would contribute to a lex mercatoria are, to a large degree, technically sophisticated, the instant proposal is not one of expert, technocratic regulation, which is a subject of some debate. See, e.g., C. M. RADAELLI, Technocracy in the European Union (London: Routledge 1999). In this case, it is merely coincidental that the regulated group itself consists largely of "technocratic" individuals.
} 
Mafia's unwritten "omerta" code of silence), but which are viewed as illegitimate by society more broadly, not to mention the legal system. ${ }^{81}$ Clearly, in order to achieve external legitimacy, a private code must hew to applicable legal rules and norms. As noted by Jaffe, such codes must be "pronounced by a court to be 'reasonable' and comfortable to the general law" and cannot simply reflect the desires of private actors. ${ }^{82}$

In the context of open source code software, Dan Wielsch has observed a concerted effort by the open source community to embody a set of "peculiar ethical imperatives" into the licensing agreements promulgated by the Free Software Foundation (FSF). ${ }^{83}$ The FSF's gesture toward a transnational lex contractus is deliberate, Wielsch argues, as it "uses a vocabulary that deliberately eschews terms of art in international copyright law in order to avoid the importation of system-specific legal assumption" and instead adopts "a language that incorporates and faithfully conveys the normativity of technological engineering projects." 84

Who, then, can be trusted with the codification effort in the context of technical standards? Could a particular SDO play the role that FSF has played with regard to the open source community? Probably not. As noted above, there is a diversity of viewpoints and backgrounds within SDOs, making it more likely that true industry consensus would only be achieved through an effort that spanned SDOs. Moreover, the act of codification is, at heart, a legal activity, so it would be preferable for the codification effort to include at least some participants with legal backgrounds. These considerations point to an industry activity organized by a neutral body that has at least some level of legal capability.

Who, then, can be trusted with this codification effort? A particular SD0? Probably not. As noted above, there is a diversity of viewpoints and backgrounds within SDOs, making it more likely that true industry consensus would be achieved through an effort that spanned SDOs. Moreover, the act of codification is, at heart, a legal activity, so it would be preferable for the codification effort to include at least some participants with legal backgrounds. These considerations point to an industry activity organized by a neutral body that has at least some level of legal credibility.

Neutrality is particularly important for the codifying body, as the proposed lex mercatoria would, in some ways, supersede decision making by the democratically sanctioned national judiciary. As such, the lex should not be biased toward any particular industry position, but should embody only those positions that reflect broad consensus within the standardization community. Capture of the codifying body by particular interests (e.g., by firms that primarily seek to monetize patent assets, or by firms that primarily manufacture products

\footnotetext{
81 See, e.g., C. J. Milhaupt \& M. D. WeSt, "The Dark Side of Private Ordering: An Institutional and Empirical Analysis of Organized Crime", 67. University of Chicago Law Review 2000, p. (41).

82 JAFFE (n 68), at 214.

83 D. WIELSCH, “Contract Interpretation Regimes", 81. Modern Law Review 2018, p. (958), at 985.

84 Ibid., at 986.
} 
without R\&D effort) would seriously compromise the perceived validity and acceptability of the resulting code.

Examples of bodies that might be both qualified and neutral in this regard include the World Intellectual Property Organisation (WIPO), which recently developed a set of arbitral procedures for FRAND disputes, 85 the American Bar Association (ABA), which has developed an annotated set of SDO policy provisions, 86 and the International Chamber of Commerce, which developed the international commercial code known as INCOTERMS. ${ }^{87}$ Each of these bodies appears to possess the necessary levels of expertise, industry contacts and, at least in some respects, neutrality, to lead the codification effort. ${ }^{88}$

One important feature of the lex mercatoria approach is that, once developed, it need not be formally adopted or approved by SDOs, which in many cases have proven to be contentious and mired in internal debate. Rather, the lex can exist outside of any particular SDO, and can be available for reference by SDOs that are interested. Of course, any SDO that strongly opposes a term or definition contained in the lex can adopt a policy statement affirmatively rejecting that term or definition, or adopting a contrary meaning of its own. But doing so does not diminish the value of the lex. In fact, the existence of such contrary statements by dissenting SDOs could serve to strengthen the force of the lex among the larger group of non-dissenting SDOs. And, if enough SDOs and SDO participants object to a particular term in the lex, there should be some way to revise or strike the term as inconsistent with a broad industry understanding.

Another pertinent question is how such a lex mercatoria would be used once developed. It could intervene in the legal system in a number of ways: as a more or less authoritative input to existing adjudicatory processes, or as a body of adjudicative principles of its own, administered and enforced outside national judicial processes, perhaps through an industry-based transnational tribunal of some kind. ${ }^{89}$ In the former case, of course, enforcement by national courts again gives rise to the possibility of divergent application of even the common vocabulary established by the lex mercatoria, but perhaps at least some degree of consistency can be achieved for the most vexing doctrinal debates in this area. After all, the historical adoption of the original lex mercatoria by English courts in the eighteenth century and the tendency of modern courts to defer to commercial practices such as the definitions offered by INCOTERMS indicate that

\footnotetext{
${ }^{85}$ See World Intellectual Prop. ORG., WIPO ADR for FRAND Disputes, http://www.wipo.int/amc/en/center/specific-sectors/ict/frand/ (visited Jul. 9, 2018).

86 ABA Patent Policy Manual (n 13) (the author led this project).

${ }^{87}$ INCOTERMS is a good example of an industry-generated code that is adopted and referenced by courts around the world. It consists of a set of defined commercial terms specifying the delivery, payment and insurance obligations of parties to commercial shipping arrangements. See, generally, J. RAMBERG, INCOTERMS 2010, 13. European Journal of Law Reform 2011, p. (380).

${ }^{88}$ A significant practical question may be precisely how such an activity would be funded, but this point is beyond the scope of this paper.

${ }^{89}$ See J. L. ContreraS, “Global Rate-Setting: A Solution for Standards-Essential Patents?” 94. Washington Law Review 2019, forthcoming, (prepublication available at https://papers.ssrn.com/sol3/papers.cfm?abstract_id=3253954).
} 
courts may, under the right circumstances, permit private actors to establish the terms of their commercial interactions.

Even more promising is the prospect of truly international enforcement and adjudication of such SDO-related disputes, a situation that is partially achieved through current international arbitration, albeit in a private and non-transparent manner. ${ }^{90}$ The author has proposed such a system, at least for the determination of FRAND royalty rates on a global basis. ${ }^{91}$ But the actual implementation of such a system is less important than the vision of a unified body of policy that it invites.

\section{Conclusion}

Technical standardization plays an important role in the global economy, yet the rules that govern this activity are subject to inconsistent interpretations by different national courts leading to market inefficiencies. Given the increasing divergence of national and organizational policy interpretations and understandings in the standardization world, a common base of understanding driven by SDO participants rather than courts and policy makers could be an attractive solution. Such a lex mercatoria of standardization could serve as an input to national courts as well as international arbitral tribunals, providing a consensus view of certain debated SDO policy provisions that is independent of the vagaries of national law.

\footnotetext{
${ }^{90}$ See ibid (discussing weaknesses in current arbitral resolution of FRAND disputes).

${ }^{91}$ See ibid.
} 